RESEARCH PAPER

\title{
Mathematical modeling of infrared assisted hot air drying of ginger slices
}

\author{
P. V. ALFIYA* AND S. GANAPATHY
}

Department of Food and Agricultural Process Engineering, Tamil Nadu Agricultural University, COIMBATORE (T.N.) INDIA

\begin{abstract}
Infra-red assisted hot air drying studies were conducted on ginger slices of diameter $20 \pm 2.5 \mathrm{~mm}$ and thickness $5 \pm 0.5 \mathrm{~mm}$. Drying experiments were executed under infra-red and hot air temperature of $60{ }^{\circ} \mathrm{C}$ with two levels of air velocities: $0.8 \mathrm{~m} / \mathrm{s}$ and $1.4 \mathrm{~m} / \mathrm{s}$. the drying rate was found to increase proportionately with the drying air velocity, thereby minimising the total drying time. Time taken for drying ginger slices from an initial moisture content of 442 per cent (d.b.) to a final moisture content of 8.4 per cent (d.b.) at $0.8 \mathrm{~m} / \mathrm{s}$ air velocity was $300 \mathrm{~min}$. Whereas, it took $210 \mathrm{~min}$ to lower the moisture content of ginger from 433.33 per cent (d.b.) to $6.67 \%$ (d.b.) under the drying air velocity of $1.4 \mathrm{~m} / \mathrm{s}$. Infrared drying temperature of 60 ${ }^{0} \mathrm{C}$ in combination with air velocity of $0.8 \mathrm{~m} / \mathrm{s}$ showed better results for quality evaluation with reduced drying times. Logarithmic model fitted the experimental data well for the whole range of temperatures $\left(\mathrm{R}^{2}=0.9989, \mathrm{RMSE}=0.0119\right.$ and $\lambda^{2}=$ $0.000140574)$.
\end{abstract}

Key Words : Infra-red, Ginger drying, Logarithmic model, Moisture ratio, Drying rate

View point paper : Alfiya, P.V. and Ganapathy, S. (2017). Mathematical modeling of infrared assisted hot air drying of ginger slices. Asian Sci., 12 (1\&2): 20-25, DOI : 10.15740/HAS/AS/12.1and2/20-25.

\footnotetext{
* Author for correspondence

P.V. Alfiya, Central Institute of Fisheries Technology, COCHIN (T.N.) INDIA
} 